Published every April, August and December

JURNAL RISET AKUNTANSI \& KEUANGAN

ISSN:2541-061X (Online). ISSN:2338-1507(Print). http://ejournal.upi.edu/index.php/JRAK

\title{
Perbandingan Kinerja Keuangan Pemerintah Kabupaten/Kota di Provinsi Jawa Barat Tahun 2009-2013
}

\author{
Jatnika Dwi Asri \\ Institut Pemerintahan Dalam Negeri (IPDN), Bandung, Indonesia
}

\begin{abstract}
This study aims to analyze the comparison of financial performance as well as analyze whether there are differences in financial performance between districts/cities in West Java Province during 2009-2013. The research used the descriptive method with quantitative data analysis technique of financial ratios as well as $T$ test and Mann-Whitney test. The results showed that city government has a higher level of independence ratio than the district. The district effectiveness ratio is very effective with an average of $120.06 \%$. T and Mann-Whitney test results showed no difference between effectiveness ratio, while independence ratio showed the difference.

Keyword: Financial performance; Effectiveness Ratio; Independence Ratio

Abstrak.Penelitian ini bertujuan untuk menganalisis perbandingan kinerja keuangan serta menganalisis apakah terdapat perbedaan kinerja keuangan antara kabupaten/kota di Provinsi Jawa Barat selama 2009-2013. Penelitian menggunakan metode deskriptif dengan teknik analisis data kuantitatif rasio keuangan serta uji T dan uji MannWhitney. Hasil penelitian menunjukkan pemerintah kota mempunyai tingkat rasio kemandirian lebih tinggi dibandingkan kabupaten. Rasio efektivitas kabupaten/kota sangat efektif dengan rata-rata 120.06\%. Hasil uji T dan Mann-Whitney menunjukkan tidak terdapat perbedaan antara rasio efektivitas, sedangkan rasio kemandirian menunjukkan perbedaan.
\end{abstract}

Kata Kunci: Kinerja Keuangan; Rasio Efektivitas; Rasio Kemandirian

Corresponding author. Email: nickeaja@gmail.com. Jalan Ir. Soekarno KM 20, Desa Cibeusi, Jatinangor, Cibeusi, Jatinangor, Kabupaten Sumedang, Jawa Barat 45363

How to cite this article. Asri, Asri, J. D. (2016). Perbandingan Kinerja Keuangan Pemerintah Kabupaten/Kota di Provinsi Jawa Barat Tahun 2009-2013. Jurnal Riset Akuntansi Dan Keuangan Program Studi Akuntansi Fakultas Pendidikan Ekonomi Dan Bisnis Universitas Pendidikan Indonesia, 4(2), 1021-1034. Retrieved from http://ejournal.upi.edu/index.php/JRAK/article/view/4037

History of article. Received: Mei 2016, Revision: Juli 2016, Published: Agustus 2016

Online ISSN: 2541-061X.Print ISSN: 2338-1507. DOI: 10.17509/jrak.v4i2.4037

Copyright@2016. Jurnal Riset Akuntansi dan Keuangan Program Studi Akuntansi FPEB UPI 


\section{PENDAHULUAN}

Berlakunya Undang-undang (UU) Nomor 32 Tahun 2004 tentang Pemerintah Daerah dan UU Nomor 33 Tahun 2004tentang Perimbangan Keuangan antara Pemerintah Pusat dan Daerah menandai pengelolaan pemerintah daerah berdasarkan otonomi daerah melalui desentralisasi kewenangan dari pemerintah pusat kepada pemerintah daerah. Diharapkan desentralisasi fiskal memberikan ruang gerak pada daerah untuk mengelola keuangan daerah sesuai dengan prioritas pembangunan dan kebutuhan daerah, namun kenyataannya tingkat ketergantungan fiskal antara daerah terhadap pusat masih tinggi. Ketergantungan fiskal terlihat dari relatif rendahnya Pendapatan Asli Daerah (PAD) dan dominannya transfer dari pusat, walaupun undang-undang telah menggarisbawahi titik berat otonomi pada kabupaten/kota, kabupaten/kota justru mengalami tingkat ketergantungan yang lebih tinggi dibandingkan provinsi (Kuncoro, 2012, hlm. 319). Hal ini menunjukkan bahwa meskipun desentralisasi telah digulirkan namun pemerintah daerah masih memiliki ketergantungan fiskal cukup besar terhadap pemerintah pusat.

Berdasarkan Deskripsi dan Analisis Anggaran Pendapatan dan Belanja Daerah (APBD) 2014, daerah dengan rasio PAD dibandingkan dengan total pendapatan daerah tertinggi adalah wilayah Jawa-Bali yaitu sebesar $37.36 \%$, sedangkan yang terendah wilayah Nusa Tenggara-Maluku-Papua yang hanya sebesar $7.08 \%$ (Direktorat Jenderal Perimbangan Keuangan, 2014a). Hal ini menunjukkan bahwa tingkat kemandirian seluruh daerah yang berada di wilayah Jawa dan Bali relatif lebih tinggi dibandingkan dengan wilayah lainnya. Gambaran komposisi realisasi pendapatan daerah untuk wilayah Jawa dan Bali seperti dijelaskan pada tabel berikut ini.

Tabel 1. Realisasi Pendapatan Daerah Jakarta, Jawa Barat dan Jawa Tengah Tahun 2014 (jutaan rupiah)

\begin{tabular}{lccc} 
& \multicolumn{3}{c}{ PROVINSI } \\
\cline { 2 - 4 } & DKI- JAKARTA & JABAR & JATENG \\
\hline PAD & $12,516,209$ & $6,878,990$ & $4,477,104$ \\
Pendapatan Transfer & $5,723,961$ & $3,693,324$ & $2,722,688$ \\
Lain-lain Pendapatan yang Sah & & 642 & 3,180 \\
Total Pendapatan & $\mathbf{1 8 , 2 4 0 , 1 7 0}$ & $\mathbf{1 0 , 5 7 2 , 9 5 6}$ & $\mathbf{7 , 2 0 2 , 9 7 2}$ \\
\hline
\end{tabular}

Tabel 2. Realisasi Pendapatan Daerah Wilayah Jaawa Timur, DIY, Banten dan Bali Tahun 2014 (jutaan rupiah)

\begin{tabular}{lcccc}
\hline & \multicolumn{5}{c}{ PROVINSI } \\
\cline { 2 - 5 } & JATIM & DIY & BANTEN & BALI \\
\hline PAD & $6,482,870$ & 673,580 & $2,273,483$ & $1,387,661$ \\
Pendapatan Transfer & $3,231,122$ & 810,178 & $1,127,958$ & 848,007 \\
Lain-lain Pendapatan yang Sah & 9,530 & 2,491 & 1,393 & 179 \\
Total Pendapatan & $\mathbf{9 , 7 2 3 , 5 2 3}$ & $\mathbf{1 , 4 8 6 , 2 4 9}$ & $\mathbf{3 , 4 0 2 , 8 3 4}$ & $\mathbf{2 , 2 3 5 , 8 4 6}$ \\
\hline
\end{tabular}


Berdasarkan tabel diatas diketahui bahwa Provinsi Jawa Barat merupakan provinsi dengan PAD dan total pendapatan terbesar setelah Provinsi DKI Jakarta. Besarnya PAD dan pendapatan tersebut memberi peluang bagi pemerintah provinsi Jawa Barat untuk memiliki tingkat kemandirian yang tinggi setelah Provinsi DKI Jakarta juga provinsi lainnya di wilayah Jawa dan Bali, serta diharapkan diikuti oleh tingkat kemandirian kabupaten dan kotanya. Dengan demikian menarik untuk dilakukan penelitian mengenai kinerja keuangan pada pemerintah kabupaten dan kota di Provinsi Jawa Barat.

Berdasarkan latar belakang di atas, rumusan masalah dalam penelitian ini antara lain: (1) Bagaimana perbandingan kinerja keuangan berdasarkan rasio kemandirian pada kabupaten dan kota di Provinsi Jawa Barat dalam kurun waktu tahun 2009 sampai dengan 2013? (2) Bagaimana perbandingan kinerja keuangan berdasarkan rasio efektivitas pada kabupaten dan kota di Provinsi Jawa Barat dalam kurun waktu tahun 2009 sampai dengan 2013? (3)Apakah terdapat perbedaan kinerja keuangan antara pemerintah kabupaten dan kota yang ada di Provinsi Jawa Barat dalam kurun waktu tahun 2009 sampai dengan 2013? Sedangkan tujuan penelitian yaitu (1) Menganalisis perbandingan kinerja keuangan berdasarkan rasio kemandirian pada kabupaten dan kota di Provinsi Jawa Barat dalam kurun waktu tahun 2009-2013 (2) Menganalisis perbandingan kinerja keuangan berdasarkan rasio efektivitas pada kabupaten dan kota di Provinsi Jawa Barat dalam kurun waktu tahun 2009-2013. (3) Menganalisis apakah terdapat perbedaan kinerja keuangan antara pemerintah kabupaten dan kota yang ada di Provinsi Jawa Barat dalam kurun waktu tahun 2009-2013.

\section{KAJIAN LITERATUR}

\section{Otonomi Daerah}

Rondinelli dan Cheema dalam Said (2008) mengatakan bahwa otonomi daerah adalah proses pelimpahan wewenang perencanaan, pengambilan keputusan atau pemerintahan dari pemerintah pusat kepada organisasi unit-unit pelaksana daerah, kepada organisasi semiotonom dan parastatal (kepemilikan oleh negara), atau kepada pemerintah daerah ataupun organisasi nonpemerintah. Suwanda (2013) mengatakan bahwa semakin tinggi derajat desentralisasi semakin tinggi pula tingkat otonomi daerah.Lebih lanjut Mardiasmo (2004, hlm. 60) mengatakan bahwa dengan pemberian otonomi dan desentralisasi kepada daerah diharapkan perekonomian daerah akan semakin kuat dan mandiri. Dari penjelasan tersebut dapat dikatakan bahwa pemberian otonomi dan desentralisasi kepada daerah yang diimbangi dengan kemampuan pengelolaan keuangan yang optimal akan meningkatkan kemandirian daerah yang pada akhirnya akan mempengaruhi kinerja keuangan daerah.

\section{Anggaran Pendapatan dan Belanja Daerah}

Badrudin (2012) mengatakan bahwa APBD merupakan rencana kerja pemerintah daerah yang mencakup seluruh pendapatan atau penerimaan dan belanja atau pengeluaran pemerintah, baik provinsi, kabupaten, dan kota dalam rangka mencapai sasaran pembangunan dalam kurun waktu satu tahun yang dinyatakan dalam satuan uang. Dengan demikian dapat dikatakan bahwa APBD merupakan alat kebijakan fiskal pemerintah daerah dalam menyusun program kerja pemerintah daerah selama satu tahun yang terdiri dari penerimaan dan pengeluaran pemerintah daerah. Mengacu pada Peraturan Menteri Dalam Negeri (Permendagri) Nomor 13 Tahun 2006 tentang Pedoman Pengelolaan Keuangan Daerah, struktur APBD meliputi seluruh pendapatan, belanja, serta pembiayaan daerah.

\section{Akuntansi Pemerintahan}

Bourmistrov dan Mellemvik (2010) mengartikan akuntansi dari perspektif hubungandiantara prinsipal dan agen. Fungsi akuntansi adalah menjadi fasilitator dalam mengurangi ketidakpastian dalam hubungan prinsipal-agen dalam rangka meningkatkan akuntabilitas, pengawasan, dan pengambilan keputusan. Lebih lanjut Sugijanto dalam Halim dan Kusufi (2012) membagi akuntansi menjadi tiga bidang utama yaitu akuntansi komersial, akuntansi pemerintahan, dan akuntansi sosial. Vela dan Fuertes (2000) mengatakan bahwa 
klasifikasi bidang akuntansi pemerintahan belum sepenuhnya diimplementasikan karena adanya masalah dalam pendefinisian faktorfaktor relevan selain heterogenitas sistem yang ada di suatu negara. Dari penjelasan tersebut, dapat ditarik kesimpulan bahwa akuntansi pemerintahan termasuk dalam lingkup akuntansi sektor publik.

\section{Laporan Keuangan Pemerintah Daerah}

Berdasarkan Peraturan Pemerintah (PP) Nomor 71 Tahun 2010, yang dimaksud dengan laporan keuangan adalah laporan terstruktur mengenai posisi keuangan dan transaksitransaksi yang dilakukan oleh suatu entitas pelaporan. Granof dan Khumawala (2013) mengemukakan bahwa secara umum laporan keuangan dapat digunakan untuk menilai kondisi keuangan, membandingkan anggaran dengan realisasi hasil, serta memenuhi kepatuhan terhadap peraturan, dan aturan penggunaan dana.

Penelitian Mauland dan Mellemvik (2010) pada pemerintah daerah di Norwegia menjelaskan terdapat empat jenis laporan keuangan yang digunakan oleh pemerintah daerah setempat, antara lain: 1) The operating statement; 2) The capital statement; 3) The fund flows statement; dan4) The balance sheet.Mengacu pada PP Nomor 71 Tahun 2010, laporan keuangan pokok pemerintah daerah di Indonesia terdiri dari: 1) Laporan Realisasi Anggaran (LRA); 2) Laporan Perubahan Saldo Anggaran Lebih (Laporan Perubahan SAL); 3) Neraca; 4) Laporan Operasional (LO); 5) Laporan Perubahan Ekuitas (LPE); 6) Laporan Arus Kas (LAK); dan 7) Catatan atas Laporan Keuangan (CaLK).

\section{Kinerja Keuangan}

Zafra-Gomez et al. (2009) menyatakan bahwa penilaian kinerja keuangan pemerintah daerah dapat dilakukan dengan menggunakan data anggaran, informasi ekonomi, maupun informasi keuangan.Kinerja keuangan merupakan alat ukur yang baik dalam menilai kinerja manajemen pemerintah lokal. Dengan demikian dapat dikatakan bahwa penilaian kinerja keuangan pemerintah daerah dapat dilakukan melalui analisis laporan keuangan pemerintah daerah yang mengacu pada standar akuntansi pemerintahan.

Lebih lanjut Mahmudi (2010) mengemukakan bahwa kinerja keuangan tercermin dari laporan keuangan neraca, laporan realisasi anggaran, dan laporan arus kas. Laporan keuangan perlu dianalisis untuk dapat memberikan gambaran kinerja keuangan. Secara umum pengukuran kinerja keuangan pemerintah daerah berguna untuk mengetahui tingkat kesehatan struktur keuangan, dan tingkat kemandirian suatu daerah dengan melihat kemampuan daerah dalam menggali sumber pendapatan daerah dibanding dengan kewajiban pemerintah dalam membiayai belanja daerah.

\section{Analisis Rasio Keuangan}

Halim (2007) yang menyatakan bahwa salah satu alat untuk menganalisis kinerja pemerintah daerah dalam mengelola keuangan daerahnya adalah dengan melakukan analisis rasio keuangan terhadap APBD yang telah ditetapkan dan dilaksanakan. Hasil analisis rasio keuangan ini selanjutnya digunakan sebagai dasar untuk: (1) Menilai kemandirian keuangan daerah dalam membiayai penyelenggaraan otonomi daerah; (2) Mengukur efektivitas dan efisiensi dalam merealisasikan pendapatan daerah; (3) Mengukur sejauh mana aktivitas pemda dalam membelanjakan pendapatan daerahnya; (4) Mengukur kontribusi masing-masing sumber pendapatan dalam pembentukan pendapatan daerah; dan (5) Melihat pertumbuhan/perkembangan perolehan pendapatan dan pengeluaran yang dilakukan selama periode waktu tertentu.

Di sisi lain, Halim (2007) mengemukakan bahwa penggunaan analisis rasio pada sektor publik khususnya terhadap APBD belum banyak dilakukan sehingga secara teori belum ada kesepakatan secara bulat mengenai nama dan kaidah pengukurannya, namun terdapat beberapa rasio yang dapat dikembangkan, antara lain rasio kemandirian, rasio efektivitas dan efisiensi, rasio aktivitas, serta Debt Service Coverage Ratio (DSCR). 
Berdasarkan penjelasan di atas, maka hipotesis dalam penelitian ini yaitu Terdapat perbedaan kinerja keuangan antara pemerintah kabupaten dan kota yang ada di Provinsi Jawa Barat dalam kurun waktu tahun 2009-2013

\section{METODOLOGI PENELITIAN}

Penelitian ini bersifat deskriptif dengan pendekatan kuantitatif. Data yang dikumpulkan merupakan data sekunder berupa data seluruh kabupaten dan kota yang ada di Provinsi Jawa Barat tahun 2009-2013yang diperoleh dari Direktorat Jenderal Perimbangan Keuangan (DJPK) Kementerian Keuangan RI. Data yang digunakan meliputi data APBD, dan Realisasi APBD yang telah diaudit pada seluruh kabupaten dan kota di Provinsi Jawa Barat.

Informasi terkait dengan data-data yang digunakan dapat disampaikan yaitu APBD Kabupaten dan Kota Tahun 2009-2013. Data yang diambil dari APBD kabupaten/kota adalah data anggaran penerimaan PAD. Realisasi APBD Kabupaten dan Kota tahun 2010-2013 Data yang diambil dari realisasi APBD kabupaten/kota antara lain data PAD, dan Total Pendapatan.

Untuk mengkonfirmasi hasil penelitian, dilakukan wawancara kepada Kepala Subbagian Akuntansi dan Pelaporan II pada Bagian Akuntansi dan Pelaporan Keuangan Daerah Biro Keuangan Sekretariat Daerah Provinsi Jawa Barat.

Objek penelitian dalam penelitian ini adalah kinerja keuangan kabupaten dan kota di Provinsi Jawa Barat tahun 2009-2013. Penilaian kinerja keuangan daerah diukur melalui pendekatan perhitungan rasio keuangan, yang meliputi rasio kemandirian, dan rasio efektivitaskeuangan daerah. Langkah-langkah pengolahan data dalam penelitian ini antara lain:

Rasio kemandirian dihitung dengan cara membandingkan antara PAD dengan Total Pendapatan, hasilnya diubah kedalam bentuk persen.

Rasio Kemandirian $=\frac{P A D}{\text { Total Pendapatan Daerah }}$
Rasio efektivitas PAD didapatkan dengan melakukan perhitungan pembagian antara realisasi penerimaan PAD dengan anggaran penerimaan PAD, kemudian hasilnya diubah menjadi bentuk persen.

Rasio Ef ektivitas $=\frac{\text { Realisasi Penerimaan } P A D}{\text { Target Penerimaan } P A D}$

Sumber: Halim (2007, hlm. 234)

Selanjutnya dibuatkan tabel untuk memberi peringkat berdasarkan rasio yang telah dihitung.

Selain peringkat kabupaten/kota dibuat untuk masing-masingrasio, dibuat pula tabel peringkat berdasarkan rata-rata rasio (rasio kemandirian dan rasio efektivitas).

Melakukan analisis data untuk menguji hipotesis dengan bantuan SPSS Versi 21.0. Metode analisis data untuk menguji hipotesis dalam penelitian ini antara lain uji KolmogorovSmirnov dan uji Mann-Whitney.

\section{HASIL DAN PEMBAHASAN}

\section{Rasio Kemandirian Keuangan Daerah}

Hasil perhitungan rasio dan peringkat (PRKT) kemandirian kabupaten dan kota di Provinsi Jawa Barat tahun 2009-2013 ditunjukkan pada tabel 2. Dalam kurun waktu 2009-2013, rasio kemampuan keuangan daerah tertinggi ditempati oleh Kabupaten Bekasi yaitu sebesar $34.34 \%$ pada tahun 2013, dan terendah oleh Kabupaten Tasikmalaya sebesar 3.18\% pada tahun 2013. Terdapat kesenjangan (gap) $31.16 \%$ di antara rasio kemandirian Kabupaten Bekasi dan Kabupaten Tasikmalaya. Selanjutnya, Kabupaten Bekasi, Kabupaten Bogor, Kota Bandung, Kota Bekasi, dan Kota Bogor merupakan kabupaten/kota yang selalu mendapatkan peringkat 7 tertinggi selama kurun waktu 2009-2013. Sebaliknya, Kabupaten Ciamis, Kabupaten Garut, Kabupaten Kuningan, Kabupaten Subang, dan Kabupaten Tasikmalaya merupakan kabupaten/kota yang selalu mendapatkan peringkat 7 terendah selama kurun waktu 2009-2013. 
Tabel 3. Rasio Kemandirian Kabupaten dan Kota di Provinsi Jawa Barat Tahun 2009-2013 (dalam Persen)

\begin{tabular}{|c|c|c|c|c|c|c|c|c|c|c|c|}
\hline \multirow[t]{2}{*}{ No. } & \multirow[t]{2}{*}{$\mathrm{KAB} / \mathrm{KOTA}$} & \multicolumn{2}{|c|}{ TAHUN 2009} & \multicolumn{2}{|c|}{ TAHUN 2010} & \multicolumn{2}{|c|}{ TAHUN 2011} & \multicolumn{2}{|c|}{ TAHUN 2012} & \multicolumn{2}{|c|}{ TAHUN 2013} \\
\hline & & RASIO & PRKT & RASIO & PRKT & RASIO & PRKT & RASIO & PRKT & RASIO & PRKT \\
\hline 1 & Kab. Bandung & 7.84 & 15 & 9.72 & 14 & 11.86 & 12 & 12.62 & 13 & 15.06 & 11 \\
\hline 2 & Kab. Bekasi & 17.69 & 1 & 14.91 & 5 & 25.35 & 3 & 28.75 & 2 & 34.34 & - \\
\hline 3 & Kab. Bogor & 15.51 & 3 & 15.90 & 4 & 20.12 & 6 & 26.51 & 6 & 27.58 & 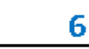 \\
\hline 4 & Kab. Ciamis & 3.79 & 26 & 3.83 & 25 & 3.68 & 25 & 4.70 & 25 & 5.35 & 25 \\
\hline 5 & Kab. Cianjur & 7.08 & 18 & 7.75 & 17 & 8.32 & 18 & 10.60 & 16 & 11.84 & 14 \\
\hline 6 & Kab. Cirebon & 9.03 & 13 & 9.40 & 15 & 10.88 & 14 & 11.53 & 14 & 10.83 & 19 \\
\hline 7 & Kab. Garut & 6.44 & 21 & 6.43 & 21 & 5.92 & 24 & 7.91 & 21 & 8.78 & 20 \\
\hline 8 & Kab. Indra mayu & 7.16 & 17 & 7.41 & 18 & 8.64 & 17 & 8.73 & 20 & 8.24 & 21 \\
\hline 9 & Kab. Karawang & 9.97 & 12 & 12.96 & 9 & 18.72 & 7 & 26.76 & 5 & 24.55 & 7 \\
\hline 10 & Kab. Kuningan & 6.69 & 20 & 6.11 & 23 & 6.33 & 23 & 6.67 & 23 & 6.92 & 24 \\
\hline 11 & Kab. Majalengka & 7.05 & 19 & 6.80 & 19 & 6.78 & 21 & 6.59 & 24 & 7.95 & 22 \\
\hline 12 & Kab. Purwa ka rta & 8.19 & 14 & 9.01 & 16 & 11.22 & 13 & 13.10 & 12 & 12.67 & 12 \\
\hline 13 & Kab. Subang & 6.09 & 22 & 6.37 & 22 & 6.70 & 22 & 7.72 & 22 & 7.89 & 23 \\
\hline 14 & Kab. Sukabumi & 5.63 & 23 & 6.48 & 20 & 8.18 & 19 & 9.11 & 19 & 11.35 & 16 \\
\hline 15 & Kab. Sumedang & 10.75 & 11 & 10.00 & 12 & 10.36 & 15 & 10.84 & 15 & 11.05 & 18 \\
\hline 16 & Kab. Tasikmalaya & 4.05 & 25 & 3.69 & 26 & 3.40 & 26 & 3.36 & 26 & 3.18 & 26 \\
\hline 17 & Kota Bandung & 14.99 & 4 & 18.11 & 2 & 26.75 & 1 & 27.42 & 3 & 33.30 & 2 \\
\hline 18 & Kota Bekasi & 15.69 & 2 & 18.71 & 1 & 25.60 & 2 & 27.28 & 4 & 32.73 & 3 \\
\hline 19 & Kota Bogor & 14.00 & 5 & 14.29 & 6 & 20.19 & 5 & 22.18 & 7 & 29.52 & 3 \\
\hline 20 & Kota Cirebon & 12.13 & 8 & 13.40 & 8 & 14.32 & 10 & 17.14 & 9 & 20.40 & 1 \\
\hline 21 & Kota Depok & 11.67 & 9 & 12.81 & 10 & 21.27 & 4 & 29.04 & 1 & 30.25 & - \\
\hline 22 & Kota Sukabumi & 13.07 & 6 & 16.19 & 3 & 18.29 & 8 & 20.26 & 8 & 20.78 & 0 \\
\hline 23 & Kota Tasikmalaya & 10.79 & 10 & 12.63 & 11 & 12.05 & 11 & 14.42 & 11 & 12.66 & 13 \\
\hline 24 & Kota Cima hi & 12.67 & 7 & 14.10 & 7 & 16.17 & 9 & 16.57 & 10 & 19.64 & 10 \\
\hline 25 & Kota Banjar & 7.18 & 16 & 9.73 & 13 & 9.39 & 16 & 10.03 & 17 & 11.37 & 15 \\
\hline 26 & Kab. Bandung Barat & 4.62 & 24 & 4.92 & 24 & 7.40 & 20 & 9.57 & 18 & 11.20 & 17 \\
\hline
\end{tabular}

Sumber: Direktorat Jenderal Perimbangan Keuangan (2014c), telah diolah kembali.

Selanjutnya untuk mengetahui peringkat dari rata-rata tingkat kemandirian kabupaten dan kota di Provinsi Jawa Barat, seperti dijelaskan pada tabel 3. Dari tabel 3 diketahui bahwa secara umum kabupaten dan kota di Provinsi Jawa Barat masih memiliki rasio kemandirian keuangan daerah di bawah 25\%. Kabupaten Bekasi menempati tingkat kemandirian peringkat pertama, dengan nilai rata-rata sebesar $24,21 \%$ yang menunjukkan bahwa PAD Kabupaten Bekasi memberikan kontribusi yang paling besar bagi total pendapatan daerahnya. Sedangkan Kabupaten Tasikmalaya menempati peringkat terakhir dari 26 kabupaten/kota di Provinsi Jawa Barat dengan nilai rata-rata $3.54 \%$. Hal ini menunjukkan bahwa tingkat ketergantungan kabupaten dan kota di Provinsi Jawa Barat masih tinggi terhadap bantuan dari pemerintah pusat maupun provinsi. Dari sisi kemandirian daerah, seluruh kota di Provinsi Jawa Barat mempunyai peringkat 11 teratas kecuali Kota Banjar. Dengan demikian dapat disimpulkan bahwa kabupaten di Provinsi Jawa Barat cenderung mempunyai tingkat ketergantungan yang lebih tinggi terhadap pemerintah pusat atau provinsi dibandingkan dengan pemerintah kotanya. 
Tabel 4. Rata-Rata Rasio Kemandirian Kabupaten dan Kota di Provinsi Jawa Barat Tahun 2009-2013 (Persen)

\begin{tabular}{|c|c|c|c|c|c|c|c|c|}
\hline \multirow{2}{*}{ NO } & \multirow{2}{*}{ КАВ/KOTA } & \multicolumn{6}{|c|}{ RASIO KEMANDIRIAN (\%) } & \multirow[t]{2}{*}{ PRKT } \\
\hline & & 2009 & 2010 & 2011 & 2012 & 2013 & RATA2 & \\
\hline 1 & Kab. Bandung & 7.84 & 9.72 & 11.86 & 12.62 & 15.06 & 11.42 & 12 \\
\hline 2 & Kab. Bekasi & 17.69 & 14.91 & 25.35 & 28.75 & 34.34 & 24.21 & 1 \\
\hline 3 & Kab. Bogor & 15.51 & 15.90 & 20.12 & 26.51 & 27.58 & 21.12 & 4 \\
\hline 4 & Kab. Ciamis & 3.79 & 3.83 & 3.68 & 4.70 & 5.35 & 4.27 & 25 \\
\hline 5 & Kab. Cianjur & 7.08 & 7.75 & 8.32 & 10.60 & 11.84 & 9.12 & 17 \\
\hline 6 & Kab. Cirebon & 9.03 & 9.40 & 10.88 & 11.53 & 10.83 & 10.34 & 15 \\
\hline 7 & Kab. Garut & 6.44 & 6.43 & 5.92 & 7.91 & 8.78 & 7.10 & 21 \\
\hline 8 & Kab. Indramayu & 7.16 & 7.41 & 8.64 & 8.73 & 8.24 & 8.04 & 19 \\
\hline 9 & Kab. Karawang & 9.97 & 12.96 & 18.72 & 26.76 & 24.55 & 18.59 & 7 \\
\hline 10 & Kab. Kuningan & 6.69 & 6.11 & 6.33 & 6.67 & 6.92 & 6.54 & 24 \\
\hline 11 & Kab. Majalengka & 7.05 & 6.80 & 6.78 & 6.59 & 7.95 & 7.03 & 22 \\
\hline 12 & Kab. Purwakarta & 8.19 & 9.01 & 11.22 & 13.10 & 12.67 & 10.84 & 13 \\
\hline 13 & Kab. Subang & 6.09 & 6.37 & 6.70 & 7.72 & 7.89 & 6.95 & 23 \\
\hline 14 & Kab. Sukabumi & 5.63 & 6.48 & 8.18 & 9.11 & 11.35 & 8.15 & 18 \\
\hline 15 & Kab. Sumedang & 10.75 & 10.00 & 10.36 & 10.84 & 11.05 & 10.60 & 14 \\
\hline 16 & Kab. Tasikmalaya & 4.05 & 3.69 & 3.40 & 3.36 & 3.18 & 3.54 & 26 \\
\hline 17 & Kota Bandung & 14.99 & 18.11 & 26.75 & 27.42 & 33.30 & 24.12 & 2 \\
\hline 18 & Kota Bekasi & 15.69 & 18.71 & 25.60 & 27.28 & 32.73 & 24.00 & 3 \\
\hline 19 & Kota Bogor & 14.00 & 14.29 & 20.19 & 22.18 & 29.52 & 20.04 & 6 \\
\hline 20 & Kota Cirebon & 12.13 & 13.40 & 14.32 & 17.14 & 20.40 & 15.48 & 10 \\
\hline 21 & Kota Depok & 11.67 & 12.81 & 21.27 & 29.04 & 30.25 & 21.01 & 5 \\
\hline 22 & Kota Sukabumi & 13.07 & 16.19 & 18.29 & 20.26 & 20.78 & 17.72 & 8 \\
\hline 23 & Kota Tasikmalaya & 10.79 & 12.63 & 12.05 & 14.42 & 12.66 & 12.51 & 11 \\
\hline 24 & Kota Cimahi & 12.67 & 14.10 & 16.17 & 16.57 & 19.64 & 15.83 & 9 \\
\hline 25 & Kota Banjar & 7.18 & 9.73 & 9.39 & 10.03 & 11.37 & 9.54 & 16 \\
\hline 26 & Kab. Bandung Barc & 4.62 & 4.92 & 7.40 & 9.57 & 11.20 & 7.54 & 20 \\
\hline
\end{tabular}

Sumber: Direktorat Jenderal Perimbangan Keuangan (2014c), telah diolah kembali. 
Lebih lanjut, dilakukan wawancara pada Subbagian Akuntansi dan Pelaporan II Biro Keuangan pada Sekretariat Daerah Provinsi Jawa Barat, yang mempunyai tugas untuk melakukan pengkajian kebijakan evaluasi laporan pertanggungjawaban pelaksanaan APBD kabupaten/kota serta menyelenggarakan koordinasi dan fasilitasi akuntansi dan pelaporan, untuk mengkonfirmasi hasil penetian. Menurut Kasubbag. Akuntansi dan Pelaporan II, tingkat kemandirian kota yang lebih besar dibandingkan dengan kabupaten dapat dilihat dari sisi perpajakan, dengan fakta penerimaan pajak seperti pajak hotel, restoran, reklame, dan parkir lebih besar didapatkan oleh kota dibandingkan kabupaten. Dengan demikian dapat dikatakan bahwa potensi penerimaan pajak (objek pajak) pemerintah kota lebih banyak dibandingkan dengan pemerintah kabupaten, kecuali kabupaten mempunyai potensi yang khusus seperti pariwisata atau daerah industri seperti halnya Kabupaten
Bekasi. Selanjutnya dijelaskan pula bahwa sampai saat ini belum ada standar atau patokan tinggi rendahnya tingkat kemandirian daerah, sehingga pada saat menganalisis tingkat kemandirian daerah hanya dilihat apakah nilainya di atas atau di bawah rata-rata.

\section{Rasio Efektivitas Pendapatan Asli Daerah}

Hasil perhitungan rasio dan peringkat (PRKT) efektivitas PAD kabupaten dan kota di Provinsi Jawa Barat dari tahun 2009 sampai 2013 seperti ditunjukkan tabel 4. Rasio efektivitas PAD tertinggi ditempati oleh Kabupaten Karawang dengan nilai efektivitas sebesar $241.05 \%$ pada tahun 2012. Sedangkan peringkat rasio efektivitas PAD terendah ditempati oleh Kabupaten Tasikmalaya dengan nilai efektivitas sebesar $62.88 \%$ pada tahun 2010. Mengacu pada kriteria umum dalam menilai efektivitas PAD (Mahmudi, 2010) maka nilai efektivitas di bawah $75 \%$ dinilai tidak efektif.

Tabel 5. Rasio Efektivitas PAD Kabupaten dan Kota Provinsi Jawa Barat Tahun 2009-2013 (Dalam Persen)

\begin{tabular}{|c|c|c|c|c|c|c|c|c|c|c|c|}
\hline \multirow[t]{2}{*}{ No. } & \multirow[t]{2}{*}{ KAB/KOTA } & \multicolumn{2}{|c|}{ TAHUN 2009} & \multicolumn{2}{|c|}{ TAHUN 2010} & \multicolumn{2}{|c|}{ TAHUN 2011} & \multicolumn{2}{|c|}{ TAHUN 2012} & \multicolumn{2}{|c|}{ TAHUN 2013} \\
\hline & & RASIO & PRKT & RASIO & PRKT & RASIO & PRKT & RASIO & PRKT & RASIO & PRKT \\
\hline 1 & Kab. Bandung & 101.19 & 19 & 120.19 & 6 & 135.10 & 5 & 133.19 & 9 & 137.80 & 3 \\
\hline 2 & Kab. Bekasi & 143.18 & 1 & 108.77 & 13 & 173.26 & 2 & 162.88 & 2 & 126.35 & 10 \\
\hline 3 & Kab. Bogor & 109.27 & 15 & 107.78 & 14 & 134.15 & 6 & 132.17 & 12 & 118.59 & 17 \\
\hline 4 & Kab. Ciamis & 110.13 & 14 & 96.58 & 22 & 106.55 & 21 & 132.22 & 11 & 130.01 & 6 \\
\hline 5 & Kab.Cianjur & 106.56 & 17 & 105.46 & 18 & 114.55 & 14 & 136.21 & 6 & 129.96 & 7 \\
\hline 6 & Kab. Cirebon & 99.97 & 22 & 105.95 & 17 & 110.87 & 18 & 109.98 & 24 & 104.52 & 23 \\
\hline 7 & Kab.Garut & 112.33 & 13 & 105.07 & 19 & 102.04 & 25 & 126.65 & 16 & 144.69 & 2 \\
\hline 8 & Kab. Indramayu & 125.93 & 6 & 103.87 & 20 & 139.67 & 3 & 150.23 & 4 & 120.81 & 15 \\
\hline 9 & Kab. Karawang & 115.87 & 9 & 148.82 & 1 & 187.97 & 1 & 241.05 & 1 & 137.69 & 4. \\
\hline 10 & Kab. Kuningan & 120.52 & 8 & 96.10 & 23 & 104.68 & 23 & 110.67 & 23 & 103.11 & 24 \\
\hline 11 & Kab. Majalengka & 127.26 & 5 & 98.50 & 21 & 106.04 & 22 & 113.12 & 22 & 113.87 & 19 \\
\hline 12 & Kab. Purwaka kta & 95.47 & 25 & 113.10 & 10 & 108.85 & 20 & 103.68 & 26 & 87.00 & 26 \\
\hline 13 & Kab. Subang & 98.35 & 23 & 106.05 & 16 & 113.11 & 15 & 126.10 & 18 & 119.49 & 16 \\
\hline 14 & Kab. Sukabumi & 92.07 & 26 & 114.35 & 8 & 120.61 & 13 & 113.28 & 21 & 125.16 & 11 \\
\hline 15 & Kab. Sumedang & 115.07 & 11 & 95.25 & 24 & 100.44 & 26 & 114.85 & 20 & 131.22 & 5 \\
\hline 16 & Kab. Tasikmalaya & 131.82 & 2 & 62.88 & 26 & 111.55 & 16 & 120.83 & 19 & 100.63 & 25 \\
\hline 17 & Kota Bandung & 96.11 & 24 & 107.20 & 15 & 136.80 & 4 & 133.11 & 10 & 107.34 & 22 \\
\hline 18 & Kota Bekasi & 100.94 & 21 & 95.23 & 25 & 122.46 & 11 & 130.98 & 14 & 111.30 & 20 \\
\hline 19 & Kota Bogor & 129.92 & 4 & 113.62 & 9 & 126.65 & 10 & 142.61 & 5 & 147.52 & 1 \\
\hline 20 & Kota Cirebon & 109.01 & 16 & 111.32 & 11 & 104.28 & 24 & 106.37 & 25 & 117.85 & 18 \\
\hline 21 & Kota Depok & 130.21 & 3 & 137.76 & 2 & 130.24 & 8 & 135.12 & 8 & 126.72 & 9 \\
\hline 22 & Kota Suka bumi & 115.64 & 10 & 137.43 & 3 & 130.54 & 7 & 126.20 & 17 & 122.32 & 14 \\
\hline 23 & Kota Tasikmalaya & 125.66 & 7 & 131.38 & 4 & 121.81 & 12 & 136.13 & 7 & 123.66 & 12 \\
\hline 24 & Kota Cima h i & 101.18 & 20 & 110.93 & 12 & 110.62 & 19 & 131.29 & 13 & 123.59 & 13 \\
\hline 25 & Kota Banjar & 105.94 & 18 & 130.41 & 5 & 111.15 & 17 & 130.73 & 15 & 127.55 & 8 \\
\hline 26 & Kab. Bandung Barat & 112.55 & 12 & 118.88 & 7 & 127.15 & 9 & 153.63 & 3 & 110.18 & 21 \\
\hline
\end{tabular}

Sumber: Direktorat Jenderal Perimbangan Keuangan (2014c), telah diolah kembali. 
Lebih lanjut, untuk mengetahui peringkat ratarata tingkat efektivitas PAD kabupaten dan kota di Provinsi Jawa Barat, dijelaskandalam tabel 5pada halaman berikut. Dari tabel tersebut dapat diketahui bahwa secara umum kabupaten dan kota di Provinsi Jawa Barat memiliki rasio efektivitas PAD di atas $100 \%$ yaitu berkisar 101.62-166.28\%. Kabupaten Karawang menempati tingkat efektivitas PAD peringkat pertama, dengan nilai rata-rata sebesar $166.28 \%$ yang menunjukkan bahwa Kabupaten Karawang mampu merealisasikan PAD yang direncanakan dibandingkan dengan PAD yang dianggarkan. Sedangkan Kabupaten Purwakarta menempati peringkat terakhir dari 26 kabupaten/kota di Provinsi Jawa Barat dengan nilai rata-rata $101.62 \%$.
Berdasarkan pembahasan di atas, selanjutnya dilakukan wawancara pada Subbagian Akuntansi dan Pelaporan II Biro Keuangan pada Sekretariat Daerah Provinsi Jawa Barat untuk mengkonfirmasi hasil penetian.Menurut penjelasan Kasubbag. Akuntansi dan Pelaporan II, efektivitas yang tinggi dapat terjadi karena: 1) Prestasi pemerintah kabupaten/kota dalam merealisasikananggaran PAD; atau 2) Penganggaran yang tidak sesuai dengan potensi daerah yang sebenarnya (underestimate). Kasubbag. Akuntansi dan Pelaporan II menjelaskan bahwa saat ini belum ada patokan khusus untuk menentukan tingkat efektivitas yang ideal, namun rasio efektivitas biasa digunakan sebagai bahan evaluasi untuk pembinaan bagi kabupaten dan kota di Provinsi Jawa Barat

Tabel 6. Rata-Rata Rasio Efektivitas PAD Kabupaten \& Kota Provinsi Jawa Barat Tahun 2009-2013 (Persen)

\begin{tabular}{|c|c|c|c|c|c|c|c|c|}
\hline \multirow[t]{2}{*}{ No. } & \multirow[t]{2}{*}{ КАВ/КОТА } & \multicolumn{6}{|c|}{ RASIO EFEKTNITAS (\%) } & \multirow[b]{2}{*}{ PERINGKAT } \\
\hline & & 2009 & 2010 & 2011 & 2012 & 2013 & RATA2 & \\
\hline 1 & Kab. Bandung & 101.19 & 120.19 & 135.10 & 133.19 & 137.80 & 125.49 & 8 \\
\hline 2 & Kab. Bekasi & 143.18 & 108.77 & 173.26 & 162.88 & 126.35 & 142.89 & 2 \\
\hline 3 & Kab. Bogor & 109.27 & 107.78 & 134.15 & 132.17 & 118.59 & 120.39 & 11 \\
\hline 4 & $\mathrm{Kab} . \mathrm{Ci}$ amis & 110.13 & 96.58 & 106.55 & 132.22 & 130.01 & 115.10 & 16 \\
\hline 5 & Kab. Cianjur & 106.56 & 105.46 & 114.55 & 136.21 & 129.96 & 118.55 & 12 \\
\hline 6 & Kab. Ci rebon & 99.97 & 105.95 & 110.87 & 109.98 & 104.52 & 106.26 & 24 \\
\hline 7 & Kab. Garut & 112.33 & 105.07 & 102.04 & 126.65 & 144.69 & 118.16 & 13 \\
\hline 8 & Kab. Indramayu & 125.93 & 103.87 & 139.67 & 150.23 & 120.81 & 128.10 & 5 \\
\hline 9 & Kab. Karawang & 115.87 & 148.82 & 187.97 & 241.05 & 137.69 & 166.28 & 1 \\
\hline 10 & Kab. Kuningan & 120.52 & 96.10 & 104.68 & 110.67 & 103.11 & 107.01 & 23 \\
\hline 11 & Kab. Majalengka & 127.26 & 98.50 & 106.04 & 113.12 & 113.87 & 111.76 & 20 \\
\hline 12 & Kab. Purwakarta & 95.47 & 113.10 & 108.85 & 103.68 & 87.00 & 101.62 & 26 \\
\hline 13 & Kab. Subang & 98.35 & 106.05 & 113.11 & 126.10 & 119.49 & 112.62 & 18 \\
\hline 14 & Kab. Sukabumi & 92.07 & 114.35 & 120.61 & 113.28 & 125.16 & 113.09 & 17 \\
\hline 15 & Kab. Sumedang & 115.07 & 95.25 & 100.44 & 114.85 & 131.22 & 111.37 & 21 \\
\hline 16 & Kab. Tasi kmalaya & 131.82 & 62.88 & 111.55 & 120.83 & 100.63 & 105.54 & 25 \\
\hline 17 & Kota Bandung & 96.11 & 107.20 & 136.80 & 133.11 & 107.34 & 116.11 & 14 \\
\hline 18 & Kota Bekasi & 100.94 & 95.23 & 122.46 & 130.98 & 111.30 & 112.18 & 19 \\
\hline 19 & Kota Bogor & 129.92 & 113.62 & 126.65 & 142.61 & 147.52 & 132.07 & 3 \\
\hline 20 & Kota Cirebon & 109.01 & 111.32 & 104.28 & 106.37 & 117.85 & 109.77 & 22 \\
\hline 21 & Kota Depok & 130.21 & 137.76 & 130.24 & 135.12 & 126.72 & 132.01 & 4 \\
\hline 22 & Kota Suka bumi & 115.64 & 137.43 & 130.54 & 126.20 & 122.32 & 126.43 & 7 \\
\hline 23 & Kota Tasikmalaya & 125.66 & 131.38 & 121.81 & 136.13 & 123.66 & 127.73 & 6 \\
\hline 24 & Kota Cimahi & 101.18 & 110.93 & 110.62 & 131.29 & 123.59 & 115.52 & 15 \\
\hline 25 & Kota Banjar & 105.94 & 130.41 & 111.15 & 130.73 & 127.55 & 121.16 & 10 \\
\hline 26 & Kab. Bandung Barat & 112.55 & 118.88 & 127.15 & 153.63 & 110.18 & 124.48 & 9 \\
\hline
\end{tabular}

Sumber: Direktorat Jenderal Perimbangan Keuangan (2014c), telah diolah kembali. 


\section{Analisis Uji Beda Kinerja Keuangan}

Dalam penelitian ini akan diuji apakah terdapat perbedaan kinerja keuangan antara pemerintah kabupaten dan kota yang ada di Provinsi Jawa Barat selama 2009-2013. Oleh sebab itu akan dilakukan uji perbedaan antara kelompok, yang terdiri dari kelompok kabupaten dan kelompok kota. Kelompok kabupaten diberi kode 1, sedangkan kelompok kota diberi kode 2 . Sebelum dilakukan uji statistik terhadap hipotesis, terlebih dahulu dilakukan uji normalitas data. Uji normalitas dalam penelitian ini menggunakan KolmogorovSmirnov Test yang bertujuan untuk menentukan metode alat uji hasil penelitian. Dari hasil uji normalitas data (KolmogorovSmirnov Test) diketahui bahwa nilai dengan asymp sig $>0.05$ yaitu rasio efektivitas sebesar 0.163 , sehingga data tersebut berdistribusi normal. Sedangkan data yang tidak berdistribusi normal dengan nilai asymp sig< 0.05 yaitu rasio kemandirian sebesar 0.009.Hasil uji asumi homogenitas ragam menunjukkan bahwa rasio kemandirian dan rasio efektivitas memenuhi asumsi homogenitas ragam dengan nilai Sig. > 0.05 . Berdasarkan uji normalitas dan uji homogenitas ragam tersebut, data rasio efektivitas memenuhi syarat dari uji beda $T$, sedangkan rasio kemandirian menggunakan uji Mann-Whitney. Setelah uji normalitas dan uji asumsi homogenitas dilakukan, selanjutnya dilakukan uji hipotesis dengan menggunakan uji $T$ untuk rasio efektivitas, sedangkan rasio kemandirian menggunakan uji Mann-Whitney. Berdasarkan hasil pengujian hipotesis dengan menggunakan uji $T$ diperoleh rasio efektivitas dengan nilai Sig. $=0.575$, niai signifikansi ini di atas kriteria 0.05. Maka $H_{0}$ tidak ditolak, dengan demikian dapat disimpulkan bahwa tidak terdapat perbedaan efektivitasdi antara pemerintah kabupaten dan kota yang ada di Provinsi Jawa Barat selama 2009-2013. Hasil ini mengacu pada kondisi bahwa rasio efektivitas PAD di antara kabupaten dan kota di Provinsi Jawa Barat selama kurun waktu tersebut relatif tidak bervariasi. Secara umum, baik kelompok kabupaten maupun kota, memiliki rasio efektivitas di atas $100 \%$ dengan fakta realisasi pajak dan retribusi masih memberikan porsi terbesar dalam pencapaian efektivitas PAD. Hasil uji normalitas data Kolmogorov-Smirnov Test, hasil uji asumi homogenitas ragam, dan hasil uji Tseperti ditunjukkan dalam tabel 7,8, dan 9 berikut ini:

Tabel 7. Hasil Uji Normalitas Data Kelompok

\begin{tabular}{llrr}
\hline & & KEMANDIRIAN & EFEKTIVITAS \\
\hline $\mathrm{N}$ & & 130 & 130 \\
Normal Parameters $^{\mathrm{a}}$ & Mean & 12.9089 & 120.0645 \\
& Std. Deviatior & 7.37744 & 20.24605 \\
Most Extreme Differences & Absolute & 0.144 & 0.098 \\
& Positive & 0.144 & 0.098 \\
& Negative & -0.094 & -0.087 \\
Kolmogorov-Smirnov Z & & 1.636 & 1.120 \\
Asymp. Sig. (2-tailed) & & 0.009 & 0.163 \\
\hline
\end{tabular}

Tabel 8. Hasil Uji Asumsi Homogenitas Kelompok

\begin{tabular}{|c|c|c|c|c|c|}
\hline \multicolumn{6}{|c|}{ Test of Homogeneity of Variances } \\
\hline & $\begin{array}{c}\text { Levene } \\
\text { Statistic }\end{array}$ & df1 & df2 2 & Sig. & \\
\hline KEMANDIRIAN & 1.836 & 1 & 128 & & 0.178 \\
\hline EFEKTIVITAS & 3.427 & 1 & 128 & & 0.066 \\
\hline
\end{tabular}


Tabel 9. Hasil Uji T Efektivitas Kelompok

\begin{tabular}{llrrrr}
\hline & Kelompok & \multicolumn{1}{c}{ N } & \multicolumn{1}{c}{ Mean } & Std. Deviation & Std. Error Mean \\
\hline EFEKTIVITAS & 1 & 85 & 119.34 & 23.22 & 2.52 \\
& 2 & 45 & 121.44 & 13.02 & 1.94 \\
\hline
\end{tabular}

Independent Samples Test

Levene's Test for

Equality of Variances

t-test for Equality of Means

95\% Confidence

Std. Error Interval of the

Sig. Mean Differenc Difference

\begin{tabular}{|c|c|c|c|c|c|c|c|c|c|c|}
\hline & & $\mathrm{F}$ & Sig. & $t$ & $D f$ & (2-tailer & Difference & . & Lower & Upper \\
\hline $\begin{array}{c}\text { Efekti } \\
\text { as }\end{array}$ & $\begin{array}{c}\text { Equal varianct } \\
\text { assumed }\end{array}$ & 3.427 & 0.066 & -0.562 & 128 & 0.575 & -2.10 & 3.74 & -9.51 & 5.30 \\
\hline
\end{tabular}

Berdasarkan hasil pengujian hipotesis dengan Provinsi Jawa Barat mempunyai tingkat menggunakanMann-Whitney diperoleh rasio ketergantungan yang lebih tinggi dibandingkan kemandirian dengan nilai Sig. $=0.000$. Nilai dengan pemerintah kota. Perbedaan tingkat signifikansi dari kemandirian di bawah kriteria kemandirian tersebut dinilai karena adanya 0.05 (asymp sig< 0.05), maka $H_{0}$ ditolak. Dengan potensi penerimaan pajak pemerintah kota yang demikian dapat disimpulkan bahwa terdapat lebih besar dari pada poteni penerimaan pajak perbedaan tingkat kemandirian yang signifikan pemerintah kabupaten. Hasil Mann-Whitney antara pemerintah kabupaten dan kota yang ada seperti digambarkan pada table

di Provinsi Jawa Barat selama 2009-2013. Hasil

ini mengacu pada fenomena kabupaten di

Tabel 10. Hasil Uji Mann-Whitney

\begin{tabular}{llrrr}
\hline & Kelompok & N & Mean Rank & Sum of Ranks \\
\hline KEMANDIRIAN & 1 & 85 & 49.89 & 4240.50 \\
& 2 & 45 & 94.99 & 4274.50 \\
& Total & 130 & & \\
\hline
\end{tabular}

\begin{tabular}{|c|c|}
\hline \multicolumn{2}{|l|}{ Test Statistics $^{\text {a }}$} \\
\hline & \\
\hline Mann-Whitney U & 585.500 \\
\hline Wilcoxon W & 4240.500 \\
\hline $\mathrm{Z}$ & -6.494 \\
\hline Asymp. Sig. (2-tailed) & 0.000 \\
\hline
\end{tabular}




\section{SIMPULAN}

Dari hasil penelitian dapat disimpulkan hal-halberikut ini: (1) Kinerja keuangan berdasarkan rasio kemandirian antara kabupaten dan kota di Provinsi Jawa Barat sangat bervariasi dalam kurun waktu 20092013 dengan gap sebesar 31.16\%. Terdapat kecenderungan bahwa pemerintah kota di Provinsi Jawa Barat mempunyai tingkat kemandirian yang lebih tinggi dibandingkan dengan pemerintah kabupaten. Berdasarkan rata-rata rasio kemandirian, Kabupaten Bekasi menempati peringkat pertama $(24.21 \%)$ dan Kabupaten Tasikmalaya berada pada peringkat terakhir (3.18\%); (2) Dari sisi efektivitas, kinerja keuangan berdasarkan rasio efektivitas PAD antara kabupaten dan kota di Provinsi Jawa Barat relatif tidak bervariasi dalam kurun waktu 2009-2013 dan dinilai sangat efektif dengan rata-rata sebesar $120.06 \%$. Berdasarkan rata-rata rasio efektivitas, Kabupaten Karawang menempati peringkat pertama (166.28\%) dan Kabupaten Purwakarta berada pada peringkat terakhir (101.62\%); (3) Berdasarkan hasil uji $T$ dan uji Mann-Whitney disimpulkan bahwa tidak terdapat perbedaan tingkat efektivitas di antara pemerintah kabupaten dan kota yang ada di Provinsi Jawa Barat selama 2009-2013. Namun terdapat perbedaan tingkat kemandirian yang signifikan antara pemerintah kabupaten dan kota yang ada di Provinsi Jawa Barat selama 2009-2013.

Berdasarkan kesimpulan di atas, terdapat beberapa saran yang diberikan antara lain: (1) Hasil penelitian ini dapat menjadi masukkan bagi pemerintah kabupaten dan kota di Jawa Barat untuk meningkatkan kinerja keuangan daerahnya, dengan cara lebih mengenal potensi daerahnya masingmasing, melakukan intensifikasi dan ekstensifikasi PAD sehingga pertumbuhan dan realisasi PAD dapat tercapai. Hal ini diperlukan dengan pertimbangan bahwa setiap daerah mempunyai potensi daerah yang berbeda. Dengan demikian diharapkan gap kinerja keuangan yang tinggi di antara kabupaten dan kota tidak akan terjadi. Selain itu, pemerintah daerah dengan kinerja keuangan rendah dapat menjadikan pemerintah daerah dengan kinerja keuangan tinggi sebagai benchmark dalam mengelola keuangan daerahnya; (2) Bagi pemerintah Provinsi Jawa Barat, diharapkan hasil pengukuran kinerja keuangan melalui rasio keuangan khususnya rasio kemandirian dapat dijadikan salah satu benchmark untuk menilai kinerja pemerintah daerah, bila perlu dibuat cluster daerah berdasarkan rasio keuangan. Contoh, bila terdapat permohonan pemekaran wilayah atau akan mengeluarkan bantuan provinsi maka pemerintah provinsi dapat memberikan pertimbangan dari sisi keuangan berdasarkan rasio keuangan ini; (3) Bagi peneliti yang tertarik untuk meneliti lebih lanjut mengenai rasio-rasio kinerja keuangan pemerintah daerah, disarankan untuk memperluas penelitian dengan menambahkan rasio efisiensi, rasio aktivitas, Debt Service Coverage Ratio (DSCR), atau rasio keuangan lainnya dengan menambahkan cakupan objek dan jangka waktu penelitian.

\section{DAFTAR PUSTAKA}

Badrudin, Rudy. 2012. "Ekonomika Otonomi Daerah". Yogyakarta: UPP STIM YKPN.

Bourmistrov, Anatoli., dan Frode Mellemvik. 2010. International Comparative Issues in Government Accounting, 91-122. "Accounting and Democratic Governance: A Comparative Study of One Norwegian and One Russian Country”. Kluwer Academic Publishers.

Direktorat Jenderal Perimbangan Keuangan. 2014a. "Deskripsi dan Analisis APBD 2014".

Direktorat Jenderal Perimbangan Keuangan. 2014b. "LGF Realisasi Semester I 2014".

Direktorat Jenderal Perimbangan Keuangan.2014c. "Data Keuangan Daerah 2009-2013”.

Granof, Michael H., dan Saleha B. Khumawala. 2013. "Governmental and Not-for-Profit Accounting: Concepts and Practices". Sixth edition. Wiley.

Halim, Abdul. 2007. "Akuntansi Sektor Publik: Akuntansi Keuangan Daerah". Edisi 3. Jakarta: Salemba Empat. 
Halim, Abdul., dan Syam Kusufi. 2012. "Akuntansi Sektor Publik: Teori, Konsep, dan Aplikasi”. Jakarta: Salemba Empat.

Kuncoro, Mudrajad. 2012. "Perencanaan Daerah: Bagaimana Membangun Ekonomi Lokal, Kota, dan Kawasan?" Jakarta: Salemba Empat.

Mahmudi. 2010. "Analisis Laporan Keuangan Pemerintah Daerah". Edisi Kedua. Yogyakarta: UPP STIM YKPN.

Mardiasmo. 2004. "Otonomi dan Manajemen Keuangan Daerah”. Yogyakarta: Penerbit Andi.

Mauland, Helge., dan Frode Mellemvik. 2010. International Comparative Issues in Government Accounting, 327-339. "Local Government Accounting in Norway: Central Norms Create Confusing Information at The Local Level”. Kluwer Academic Publishers.

Pemerintah Republik Indonesia. 2006.Peraturan Menteri Dalam Negeri Nomor 13 Tahun 2006 tentang Pedoman Pengelolaan Keuangan Daerah.

Pemerintah

Republik Indonesia.2010.Peraturan Pemerintah Nomor 71 Tahun 2010 tentang Standar Akuntansi Pemerintahan.

Pemerintah Republik Indonesia. 2004.UndangUndang Nomor 32 Tahun 2004 tentang Pemerintah Daerah.

Pemerintah Republik Indonesia. 2004.UndangUndang Nomor 33 tahun 2004 tentang Perimbangan Keuangan antara Pemerintah Pusat dan Pemerintah Daerah.

Said, Mas'ud. 2008. "Arah Baru Otonomi Daerah di Indonesia". Malang: UPT Penerbitan Universitas Muhammadiyah Malang.

Suwanda, Dadang. 2013. "Strategi Mendapatkan Opini WTP Laporan Keuangan Pemda”. Jakarta: Ppm Manajemen.

Vela, Jose Manuel., dan Iluminada Fuertes (2000). Comparative Issues in Local Government Accounting, 87-99. "Local Government Accounting in Europe: A
Comparative Approach”. Kluwer Academic Publishers.

Winarso. 2010. "Pengukuran Kinerja Keuangan Pemerintah Daerah". Makassar: Kopel Indonesia.

Zafra-Gomez, Jose Luis., Antonio Manuel Lopez-Hernandez., dan Agustin Hernandez-Bastida (2009). Evaluating Financial Performance in Local Government: Maximazing the Benchmarking Values. International Review of Administrative Sciences 2009, 75, 151. Juli 12, 2015. http://www.ppmrn.net/storage/ppmrn/zaf ragmez_lpezhernndez hernndezbastida_2009.pdf 


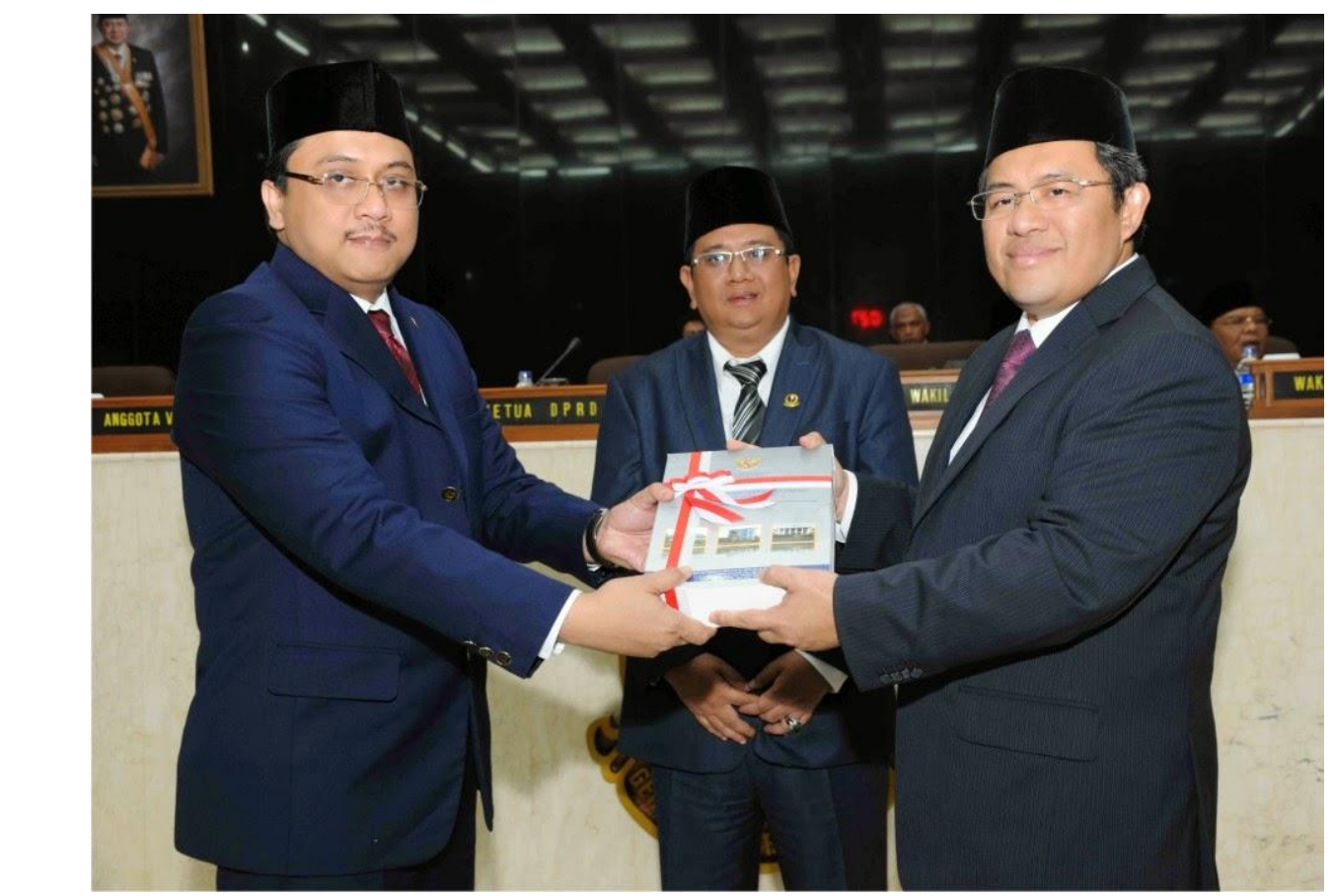

http://1.bp.blogspot.com/ wiz3NHsmj3E/U6DFtShy9rI/AAAAAAAAK58/9Ohudm9FmHs/s1600/Graphic1aherwtp.jpg

Dokumentasi Laporan Hasil Pemeriksaan (LHP) atas Laporan Keuangan Pemerintah Daerah (LKPD)

Provinsi Jawa Barat untuk Tahun Anggaran (TA) 2013-2014 memberikan opini Wajar Tanpa

Pengecualiaan (WTP). Laporan disampaikan oleh Anggota V BPK RI dalam Rapat Paripurna Istimewa DPRD Provinsi Jawa Barat di Gedung DPRD Jawa Barat

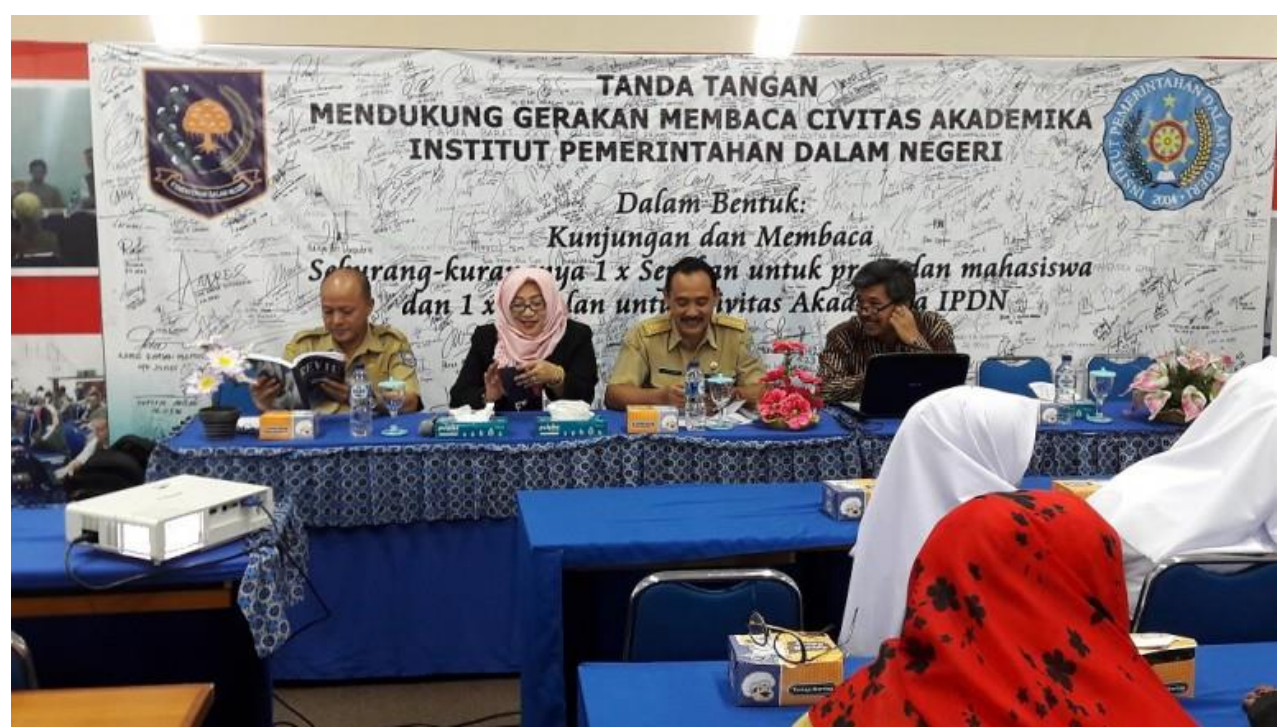

http://lib.ipdn.ac.id/wp-content/uploads/2016/08/20160815_084527-1-770x433.jpg

Dalam rangka mendukung perkuliahan dan menambah wawasan civitas akademika IPDN, pada hari Senin 15 Agustus 2016 Unit Perpustakaan IPDN Kampus Jatinangor menyelenggarakan kegiatan bedah buku. Bertempat di lantai 2 gedung perpustakaan IPDN Jatinangor kegiatan ini dihadiri oleh narasumber, pembedah, dan peserta dari berbagai instasi dan berbagai bidang ilmu 